\title{
Prevalence of sexually transmitted infections among foreigners living in Guangzhou, China: a cross-sectional study (2010-2017)
}

Benard Chimungu ${ }^{1 \dagger}$, Muqing Fu ${ }^{1 \dagger}$, Jian $\mathrm{Wu}^{2+}$, Jiali Wu', Liping Huang ${ }^{3}$, Yingchun Dai ${ }^{3}$, Shixing Tang ${ }^{3}$, Jianming Zhang ${ }^{2^{*}}$ and Chengsong Wan ${ }^{1,4^{*}}$

\begin{abstract}
Background: The prevalence of HIV/HCV/HBV/ Treponema pallidum is an essential health issue in China. However, there are few studies focused on foreigners living in China. This study aimed to assess the prevalence and sociodemographic distribution of HIV, HBV, HCV, and T. pallidum among foreigners in Guangzhou in the period of 20102017.

Methods: A cross-sectional study was conducted to screen serological samples of 40,935 foreigners from 2010 to 2017 at the Guangdong International Travel Health Care Center in Guangzhou. Samples were tested for hepatitis B surface antigen (HBsAg), anti-HCV, syphilis antibody (anti-TPPA) and anti-HIV 1 and 2. We collected secondary data from laboratory records and used multiple logistic regression analyses to verify the association between different factors and the seroprevalence of HIV/HBV/HCV/ T. pallidum.

Results: The prevalence of HBV/HCV/HIV/ T. pallidum was 2.30, 0.42, 0.02, and 0.60\%, respectively, and fluctuated slightly for 7 years. The results of multiple logistic regression showed that males were less susceptible to HBV than females (odds ratio $[O R]=0.77,95 \% \mathrm{Cl}: 0.67-0.89)$. Participants under the age of 20 had a lower risk of HBV (OR $=$ $0.25,95 \%$ Cl: $0.18-0.35)$, HCV (OR=0.06, 95\% Cl: 0.02-0.18), and T. pallidum (OR=0. 10, 95\% Cl: 0.05-0.20) than participants over the age of 50 . Participants with an education level below high school were more likely to have HBV $(\mathrm{OR}=2.98,95 \% \mathrm{Cl}: 1.89-4.70)$ than others, and businessmen ( $\mathrm{OR}=3.02,95 \% \mathrm{Cl}: 2.03-4.49)$, and designers $(\mathrm{OR}=$ 3.83, 95\% Cl: 2.49-5.90) had a higher risk of T. pallidum than others. Co-infection involved 58 (4.20\%) total cases, and the highest co-infection rate was observed for HBV and T. pallidum (2.60\%).

Conclusion: The prevalence of HBV/HCV/HIV/ T. pallidum was low among foreigners in Guangzhou. Region, gender, age, educational level, and occupation were risk factors for positive infection.
\end{abstract}

Keywords: HBV, HCV, HIV, Treponema pallidum, Prevalence, China

\footnotetext{
*Correspondence: gzwcs@smu.edu.cn; gzzhangjm@163.com

${ }^{+}$Benard Chimungu, Muqing Fu and Jian Wu contributed equally to this work.

${ }^{2}$ Clinical laboratory, Guangdong International Travel Health Care Center, Guangzhou 510635, China

'Department of Microbiology, School of Public Health, Southern Medical University, Guangzhou 510515, China

Full list of author information is available at the end of the article
} 


\section{Background}

Sexually transmitted infections (STIs) have been recognized as major public health problems in many countries, especially in developing countries [1]. Hepatitis $B$ virus (HBV) infection is considered to be a serious public health problem worldwide, especially in less developed countries. It is estimated that $70 \%$ of new chronic $\mathrm{HBV}$ infections occur in low-income countries [2]. More so, The Polaris Observatory's collaborators reported in a survey of 128 countries that the global average $\mathrm{HBV}$ prevalence rate was $4.9 \%$, with China, India, Nigeria, Indonesia, and the Philippines accounting for more than $57 \%$ of all HBsAg-positive cases [3]. The major burden from $\mathrm{HCV}$ infection comes from chronic infection [4], as 184 million individuals worldwide are chronic carriers of $\mathrm{HCV}[5,6]$. HIV has been spreading from highrisk populations to the general population [7], and 37 million individuals are living with HIV globally. In addition, around six million individuals are infected with T. pallidum [8]. Although T. pallidum had been eliminated from China in the 1960s by providing free screening and treatment, the first resurgent cases were recognized in China in 1979, and China's national surveillance data show a disturbing steady spread of the disease across the country [9]. T. pallidum has been found to increase HIV infection by two to five times. HIV infection may also increase the spreading of other sexually transmitted diseases, leading to epidemiological synergies between HIV and other STIs [10]. Thus, awareness of co-infection is important because shared transmission pathways and mechanisms may suggest common preventive interventions. In addition, $\mathrm{HBV}, \mathrm{HCV}, \mathrm{HIV}$, and syphilis can also be transmitted by mother-to-child or iatrogenic transmission, such as contaminated blood or unsterilized dental needles and syringes.

Guangdong is a province in the south of China with an estimated population of 300,000 foreigners. Guangzhou is the capital city of Guangdong. A population of foreigners lives in Guangzhou mostly for economic reasons. Currently, the prevalence of STIs among this population has not been adequately confirmed. To assess the prevalence of HIV, HBV, HCV, and $T$. pallidum among foreigners living in Guangzhou, we designed a cross-sectional study from 2010 to 2017.

\section{Methods}

\section{Study design, setting, and subjects}

A cross-sectional study was approved by the "Guangdong International Travel Healthcare Center Institutional Review Board Committee." All foreigners arriving in Guangzhou should attend Guangdong
Table 1 Demographic characteristics of participants, Guangzhou, 2010-2017

\begin{tabular}{|c|c|c|}
\hline \multirow{2}{*}{$\frac{\text { Characteristic }}{\text { Total }}$} & \multicolumn{2}{|c|}{ Number \% } \\
\hline & 40,935 & 100.00 \\
\hline \multicolumn{3}{|l|}{ Exam year } \\
\hline 2010 & 4089 & 9.99 \\
\hline 2011 & 4665 & 11.40 \\
\hline 2012 & 4464 & 10.91 \\
\hline 2013 & 5287 & 12.92 \\
\hline 2014 & 5907 & 14.43 \\
\hline 2015 & 5461 & 13.34 \\
\hline 2016 & 5605 & 13.69 \\
\hline 2017 & 5457 & 13.33 \\
\hline \multicolumn{3}{|l|}{ Region } \\
\hline Africa & 5927 & 14.48 \\
\hline Europe & 13,071 & 31.93 \\
\hline North America & 9091 & 22.21 \\
\hline South America & 2269 & 5.54 \\
\hline Oceania & 693 & 1.69 \\
\hline Asia & 9884 & 24.15 \\
\hline \multicolumn{3}{|l|}{ Gender } \\
\hline male & 23,309 & 56.94 \\
\hline female & 17,626 & 43.06 \\
\hline \multicolumn{3}{|l|}{ Age group } \\
\hline$<20$ & 6492 & 15.86 \\
\hline $20-29$ & 14,236 & 34.78 \\
\hline 30-39 & 9804 & 23.95 \\
\hline $40-49$ & 5557 & 13.58 \\
\hline$\geq 50$ & 4846 & 11.84 \\
\hline \multicolumn{3}{|l|}{ Education level } \\
\hline Less than high school & 371 & 0.91 \\
\hline High school & 10,620 & 25.94 \\
\hline Undergraduate & 18,791 & 45.90 \\
\hline Bachelor degree or above & 7582 & 18.52 \\
\hline Unknown & 3571 & 8.72 \\
\hline \multicolumn{3}{|l|}{ Occupation } \\
\hline Business & 9856 & 24.08 \\
\hline Designers/science education & 4818 & 11.77 \\
\hline Students & 12,102 & 29.56 \\
\hline Unemployed & 2537 & 6.20 \\
\hline Others & 11,622 & 28.39 \\
\hline \multicolumn{3}{|l|}{ STIS } \\
\hline HBV & 943 & 2.30 \\
\hline $\mathrm{HCV}$ & 173 & 0.42 \\
\hline HIV & 7 & 0.02 \\
\hline TPPA & 246 & 0.60 \\
\hline
\end{tabular}




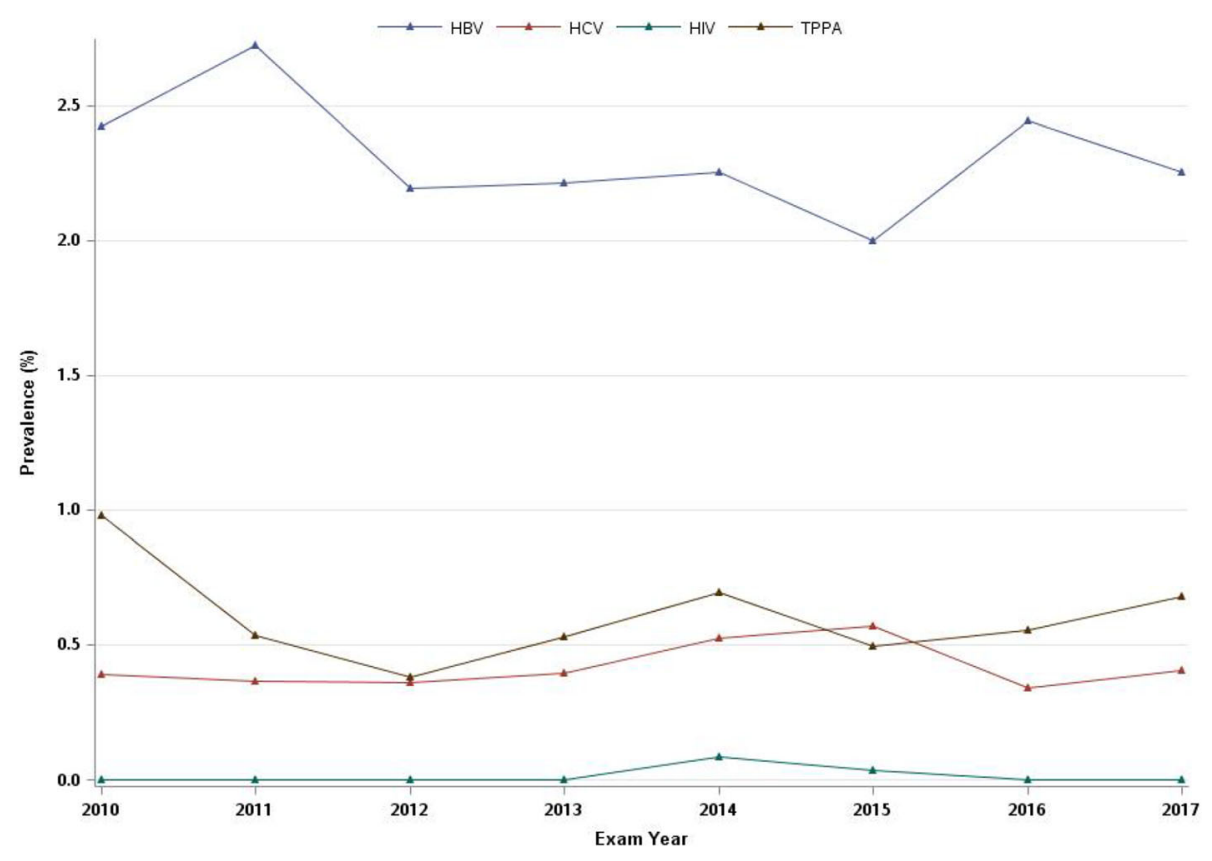

Fig. 1 The positive rate of STIs screening during 2010-2017

International Travel Health Care for physical examination within 6 months. Except for people with incomplete data (The data is not shown in the text), all the other foreigners were included in our study. This study was conducted anonymously. Within the study period, a total of 40, 935 people participated serological tests, including Antibody test for hepatitis B surface antigen (HBsAg), Antibody test for Hepatitis C Virus (anti HCV), Antibody test for HIV 1 and 2 (anti HIV), and T. pallidum gelatin agglutination test (anti T. pallidum/TPPA). We collected secondary data for analysis.

\section{Statistical analysis}

The difference in the prevalence of STIs between groups was compared using the $\mathrm{X}^{2}$ tests. Multiple logistic regression analyses were performed to explore the factors associated with seropositivity. The statistically significant variables, according to the $x^{2}$ tests, were included in the multiple logistic regression models to compute the adjusted odds ratios (OR) with $95 \%$ confidence intervals (CI). The significance level was set at $P<0.05$. All of the analyses were performed using SPSS 20.0.

\section{Results}

\section{Sociodemographic characteristics}

Of the 40, 935 participants, 23,309 (56.94\%) were male and 17,626 (43.06\%) were female. The average ages of the participates were $32.59 \pm 11.86$ years, with a range of $0-97$ years (supplementary Table 1). As shown in Table $1,45.90 \%$ of the participants were undergraduate students $(N=18,791)$, while $72.75 \%$ had a college education level or less. The majority of participants were from Europe (31.93\%) and North America (22.21\%). About $29.56 \%$ were students, followed by businessmen (24.08\%).

\section{Prevalence of STIs}

The prevalence of $\mathrm{HBV}, \mathrm{HCV}, \mathrm{HIV}$, and T. pallidum was $2.30,0.42,0.02$, and $0.60 \%$, respectively (Table 1 ), and fluctuated slightly over the 7 years covered by the study (Fig. 1). It was found that 58 (4.2\%) cases had multiple infections (Fig. 2), and the highest coinfection rate was observed for $\mathrm{HBV}$ and $T$. pallidum (2.6\%) (supplementary Table 1).

As shown in Table 2, females had a higher prevalence of $\operatorname{HBV}\left(\mathrm{X}^{2}=7.58, P=0.01\right)$ than males (see Table 2, Fig. 3). There were no differences over the exam year among the STIs. The seroprevalence of HIV, HBV, HCV, and T. pallidum presented was different by geographical regions (see Table 2, Fig. 3). There was a significant difference in the seropositivity of HBV between the different age groups $\left(\chi^{2}=14.15\right.$, $P=0.01)$. Educational level differences were also observed in the seroprevalence of $\operatorname{HBV}\left(\chi_{2}=14.94, P=\right.$ $0.01)$ and T. pallidum $(\chi 2=14.09, P=0.01)$. Considering the occupation, there were significant differences 


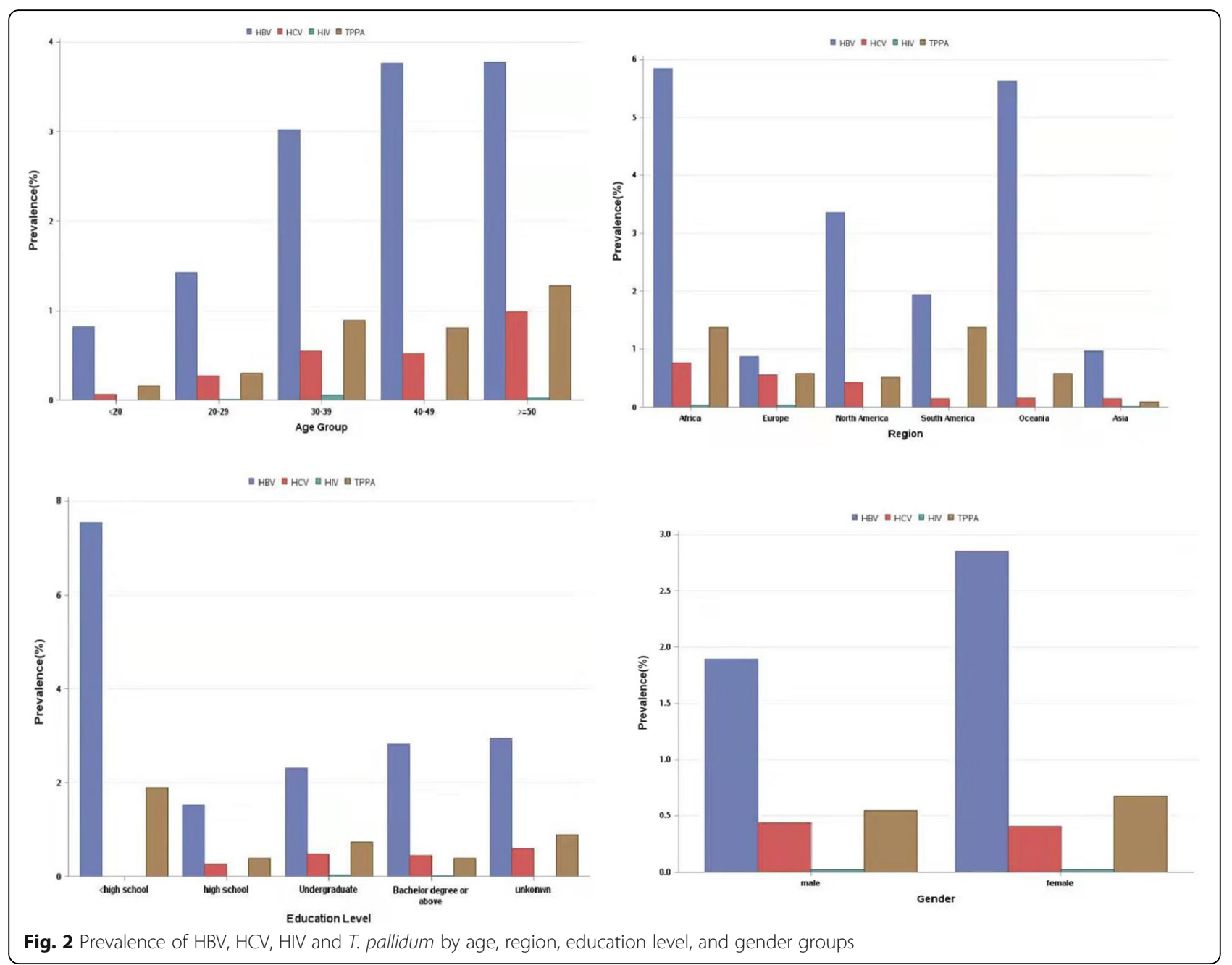

for $\operatorname{HBV}\left(\chi^{2}=64.21, P<0.001\right), \operatorname{HCV}\left(\chi^{2}=26.19, P<\right.$ $0.001)$ and $T$. pallidum $\left(\chi^{2}=155.94, P<0.001\right)$. However, perhaps as a consequence of the low number of HIV positive cases, the seropositivity of HIV was not different among the different social demographic characteristics.

\section{Related factors of STIs}

The results of multiple logistic regression showed that the seroprevalence of $\mathrm{HIV}, \mathrm{HBV}, \mathrm{HCV}$, and T. palli$d u m$ varies according to the geographical region of origin. Infection with $\mathrm{HBV}, \mathrm{HCV}$, and $T$. pallidum was the most prevalent in foreigners from Africa. Participants from Africa (OR =9.13, 95\% CI: 6.84-12.19), North America (OR = 2.74, 95\% CI: 2.08-3.60), South America $(\mathrm{OR}=2.22$, 95\% CI:1.49-3.30), and Oceania $(\mathrm{OR}=6.05,95 \% \mathrm{CI}: 4.02-9.10)$ had a higher seroprevalence of $\mathrm{HBV}$ than those from Asia. The seroprevalence of $\mathrm{HCV}$ in foreigners from Africa $(\mathrm{OR}=$
5.33, 95\% CI: 2.88-9.87) and Europe $(\mathrm{OR}=3.06,95 \%$ CI: 1.72-5.46) was higher than in those from Asia, and the seroprevalence of $T$. pallidum in Asiatic foreigners was lower than in those from Africa $(\mathrm{OR}=$ 17.18, 95\% CI: 8.17-36.11) and South America (OR = 19.30, 95\% CI: 8.81-42.29).

Among age groups, a significant increase in the positive rate of HBV was observed in the 40-49-yearold participants $(\mathrm{OR}=1.05,95 \% \mathrm{CI}$ : 0.85-1.30) (see Table 3), and people under 50 had a lower seroprevalence of $\mathrm{HCV}$ than people over 50, especially those below 20 ( $\mathrm{OR}=0.06,95 \% \mathrm{CI}$ : $0.02-0.18)$. The same is true for $T$. pallidum $(P<0.001)$. Educational level differences in seroprevalences were also observed, as people with below high school diplomas had a higher seroprevalence of HBV than other groups $(\mathrm{OR}=2.98$, 95\% CI: 1.89-4.69), and people with bachelor degree had a higher seroprevalence of $\mathrm{HBV}$ than other groups $(\mathrm{OR}=1.38,95 \% \mathrm{CI}: 1.07-1.78)$. 
Table 2 Prevalence of HBV/HCV/HIV/TPPA among individuals with different social demographic characteristics

\begin{tabular}{|c|c|c|c|c|c|c|c|c|c|c|c|c|c|}
\hline \multirow[t]{2}{*}{ Characteristic } & \multirow[t]{2}{*}{ Total } & \multicolumn{12}{|c|}{ No. Positive, (\%) } \\
\hline & & $\mathrm{HBV}$ & $x^{2}$ & $P$ & $\mathrm{HCV}$ & $x^{2}$ & P & HIV & $x^{2}$ & $P$ & TPPA & $x^{2}$ & $P$ \\
\hline \multicolumn{14}{|l|}{ Exam year } \\
\hline 2010 & 155 & 99 (2.42) & 13.61 & 0.06 & $16(0.39)$ & 8.72 & 0.27 & $0(0)$ & $18.85^{\mathrm{a}}$ & $0.001^{\mathrm{a}}$ & $40(0.98)$ & 11.70 & 0.11 \\
\hline 2011 & 169 & $127(2.72)$ & & & $17(0.36)$ & & & $0(0)$ & & & $25(0.54)$ & & \\
\hline 2012 & 131 & $98(2.20)$ & & & $16(0.36)$ & & & $0(0)$ & & & $17(0.38)$ & & \\
\hline 2013 & 166 & $117(2.21)$ & & & $21(0.40)$ & & & $0(0)$ & & & $28(0.53)$ & & \\
\hline 2014 & 210 & $133(2.25)$ & & & $31(0.52)$ & & & $5(0.08)$ & & & $41(0.69)$ & & \\
\hline 2015 & 169 & $109(2.00)$ & & & $31(0.57)$ & & & $2(0.04)$ & & & $27(0.49)$ & & \\
\hline 2016 & 187 & $137(2.44)$ & & & $19(0.34)$ & & & $0(0)$ & & & $31(0.55)$ & & \\
\hline 2017 & 182 & $123(2.25)$ & & & $22(0.40)$ & & & $0(0)$ & & & $37(0.68)$ & & \\
\hline \multicolumn{14}{|l|}{ Gender } \\
\hline Male & 673 & $440(1.89)$ & 7.58 & 0.01 & $102(0.44)$ & 7.61 & 0.01 & $4(0.02)$ & $0.18^{\mathrm{a}}$ & $0.67^{\mathrm{a}}$ & $127(0.54)$ & 0.73 & 0.39 \\
\hline Female & 696 & $503(2.85)$ & & & $71(0.40)$ & & & $3(0.02)$ & & & $119(0.68)$ & & \\
\hline \multicolumn{14}{|l|}{ Region } \\
\hline Africa & 474 & $346(5.84)$ & 125.37 & $<0.001$ & $45(0.76)$ & 67.12 & $<0.001$ & $2(0.03)$ & $8.91^{\mathrm{a}}$ & $0.11^{\mathrm{a}}$ & $81(1.37)$ & 67.96 & $<0.001$ \\
\hline Europe & 266 & $114(0.87)$ & & & $72(0.55)$ & & & $4(0.03)$ & & & $76(0.58)$ & & \\
\hline North America & 389 & 305 (3.35) & & & $38(0.42)$ & & & $0(0)$ & & & $46(0.51)$ & & \\
\hline South America & 78 & 44 (1.94) & & & $3(0.13)$ & & & $0(0)$ & & & $31(1.37)$ & & \\
\hline Oceania & 44 & $39(5.63)$ & & & $1(0.14)$ & & & $0(0)$ & & & $4(0.58)$ & & \\
\hline Asia & 118 & $95(0.96)$ & & & $14(0.14)$ & & & $1(0.01)$ & & & $8(0.08)$ & & \\
\hline \multicolumn{14}{|l|}{ Age group } \\
\hline$<20$ & 67 & $53(0.82)$ & 14.15 & 0.01 & $4(0.06)$ & 8.02 & 0.09 & $0(0)$ & $6.41^{\mathrm{a}}$ & $0.17^{\mathrm{a}}$ & $10(0.15)$ & 5.94 & 0.20 \\
\hline $20-29$ & 283 & $202(1.42)$ & & & $38(0.27)$ & & & $1(0.01)$ & & & $42(0.30)$ & & \\
\hline $30-39$ & 442 & $296(3.02)$ & & & $54(0.55)$ & & & $5(0.05)$ & & & $87(0.89)$ & & \\
\hline $40-49$ & 283 & 209 (3.76) & & & $29(0.52)$ & & & $0(0)$ & & & $45(0.81)$ & & \\
\hline$\geq 50$ & 294 & $183(3.78)$ & & & $48(0.99)$ & & & $1(0.02)$ & & & $62(1.28)$ & & \\
\hline \multicolumn{14}{|l|}{ Education level } \\
\hline Less than high school & 35 & $28(7.55)$ & 14.94 & 0.01 & $0(0)$ & 5.70 & 0.22 & $0(0)$ & $2.81^{\mathrm{a}}$ & $0.59^{\mathrm{a}}$ & $7(1.89)$ & 14.09 & 0.01 \\
\hline High school & 232 & $161(1.52)$ & & & $28(0.26)$ & & & $1(0.01)$ & & & $42(0.40)$ & & \\
\hline Undergraduate & 666 & $435(2.31)$ & & & $90(0.48)$ & & & $5(0.03)$ & & & $136(0.82)$ & & \\
\hline Bachelor degree or above & 278 & $214(2.82)$ & & & $34(0.45)$ & & & $1(0.01)$ & & & $29(0.38)$ & & \\
\hline Others & 158 & 105 (2.94) & & & $21(0.59)$ & & & $0(0)$ & & & $32(0.9)$ & & \\
\hline \multicolumn{14}{|l|}{ Occupation } \\
\hline Businessmen & 227 & $127(1.29)$ & 64.21 & $<0.001$ & $14(0.14)$ & 26.19 & $<0.001$ & $1(0.01)$ & $3.51^{\mathrm{a}}$ & $0.48^{\mathrm{a}}$ & $85(0.86)$ & 155.94 & $<0.001$ \\
\hline Designers & 200 & 105 (2.18) & & & $23(0.48)$ & & & $2(0.04)$ & & & $70(1.45)$ & & \\
\hline Students & 340 & $250(2.07)$ & & & $33(0.27)$ & & & $3(0.02)$ & & & $54(0.45)$ & & \\
\hline Unemployed & 24 & $21(0.83)$ & & & $1(0.04)$ & & & $0(0)$ & & & $2(0.08)$ & & \\
\hline Others & 578 & 440 (3.79) & & & $102(0.88)$ & & & $1(0.01)$ & & & $35(0.3)$ & & \\
\hline
\end{tabular}

${ }^{a}$ for likelihood ratio chi-square; No., OR, N/A, and 95\% Cl represent Number, Odd Rate, No data, and 95\% confidence interval, respectively

For occupation, there were significant differences in HBV for businessmen (OR $=0.31,95 \%$ CI: 0.25-0.38), designers $(\mathrm{OR}=0.30,95 \% \mathrm{CI}: 0.24-0.38)$, students $(\mathrm{OR}=$ 0.57, 95\% CI: $0.48-0.68)$, and unemployed $(\mathrm{OR}=0.16$,
95\% CI: 0.10-0.25) compared to others (Table 3). Notably, T. pallidum had a higher prevalence among businessmen $(\mathrm{OR}=3.02$, 95\% CI: 2.03-4.49) and designers $(\mathrm{OR}=3.83$, 95\% CI: 2.49-5.90) than in the other groups (Table 4). 


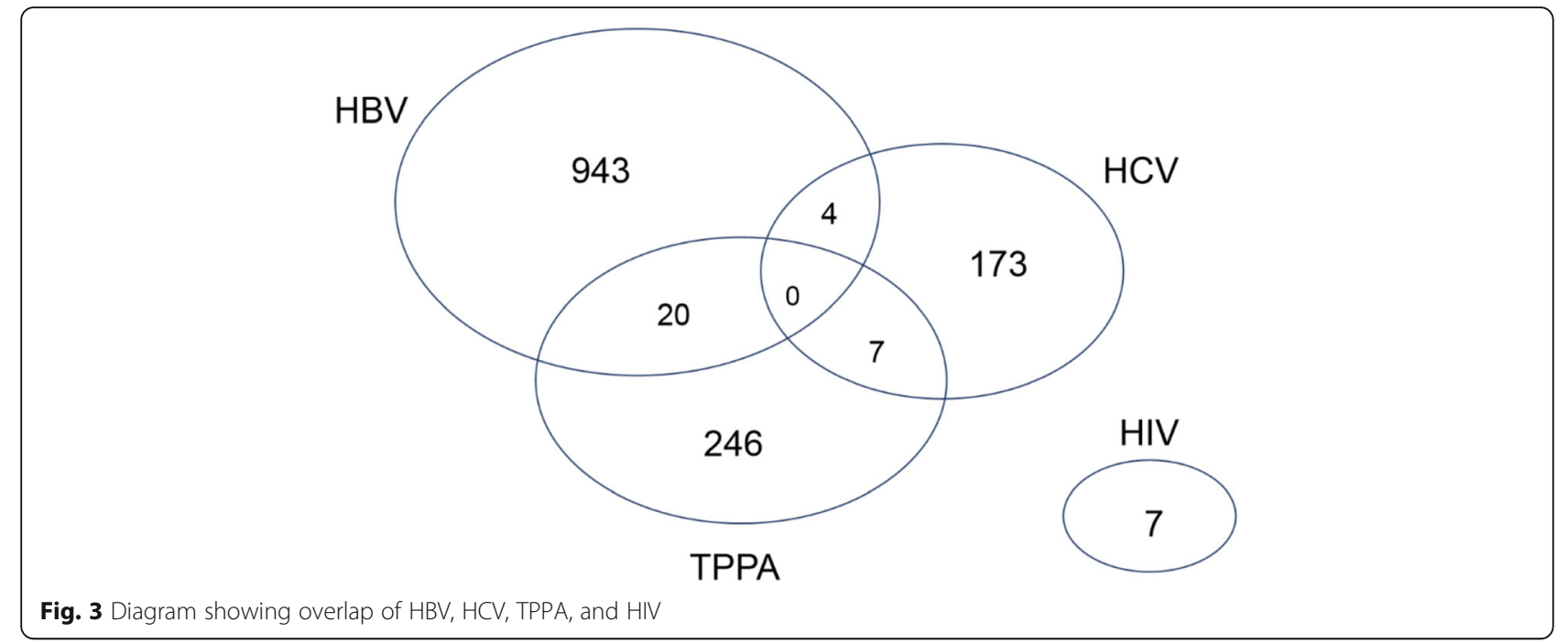

\section{Discussion}

There is an epidemic in China of sexually transmitted diseases and the potential for its continued growth in the future. In addition to sexual transmission, these diseases can also be transmitted through mother-tochild transmission, hospital transmission and so on, so controlling and preventing the spread of STIs are now on the agenda $[11,12]$. China set out to expand the comprehensive control program consisting of primary and secondary prevention strategies to ensure that STIs can be prevented and infected individuals can be diagnosed and treated in a timely fashion, especially high-risk individuals [13]. However, available data about the prevalence of STIs in foreigners are limited. This is the first large-scale study that detected the seroprevalences of HBV, HCV, HIV, and $T$. pallidum among foreigners in China.

Of the 40, 935 participants involved, 3.20\% $(N=$ 1311) had a single infection, and $0.14 \%(N=58)$ had multiple infections. A recent study in China showed that the prevalence of HBV in people aged 1-4 years, 5-14 years, and 15-29 years was 0.32, 0.94, and $4.38 \%$, respectively [14], in this research, the seropositivity of $\mathrm{HBV}$ was $2.30 \%(N=943)$, with the increase of age, the HBV infection rate gradually increased and peaked in the group aged over 50 years, which was in accordance with data for the general population. Foreigners from Africa had the highest proportion of positive $\mathrm{HBV}$ rate (5.84\%), which is higher than the $4.7 \%$ reported in Ethiopia, and lower than the 7.51, 11.2, and $14.96 \%$ reported in Benin [15], Cameroon [16], and Burkina Faso [17], respectively.

$\mathrm{HCV}$ seroprevalence among foreigners was $0.42 \%$, which is similar to the $0.43 \%$ reported in the general population in 2006 in China [18], and it is significantly lower than $2.8 \%$, the average level in the world [19]. Similarly, Africa had the highest rate of HCV infection $(0.76 \%)$, a value that is higher than the $0.5 \%$ reported in Portharcourt [20] and the $0.4 \%$ in Ethiopia [21].

Recently, it has been reported that the seroprevalence of $T$. pallidum ranged from 0.31 to $0.70 \%$ among blood donors in different areas of China [2224]. In our study, the seroprevalence of T.pallidum $(0.60 \%)$ was similar in Guangzhou (0.66\%) in 2010 [22], and higher than in Nanjing $(0.36 \%)$ and Xi'an [23]. Africa and South America had the highest rate of T.pallidum infection. In sub-Saharan Africa, T. pallidum still remains a severe public health problem [25]. When compared with African countries, the seroprevalence of $T$. pallidum infection in our study was significantly lower.

The seroprevalence of HIV in this study was $0.02 \%$. The prevalence rate of HIV infection reported in Guangzhou and Nanjing is 0.02 and $0.08 \%$, respectively [26], whereas in Western China the prevalence of HIV in donors was $0.31 \%[27,28]$. It is worth noting that there were seven HIV infection cases in total, and five cases were undergraduates, suggesting that college students are still the main group of HIV infection. The prevalence of STIs co-infection was $4.20 \%$ in foreigners, and the HBV/ T. pallidum co-infection had the maximum proportion. There were no cases involving HIV with any other pathogens. It is possible that the policy related to HIV infection in the country of origin may explain the low prevalence observed in this research. For instance, some travellers may not be allowed to go abroad due to a HIV positive test in their country. 
Table 3 Association of HBV/HCV with different social demographic characteristics

\begin{tabular}{|c|c|c|c|c|c|c|}
\hline \multirow[b]{2}{*}{ Characteristics } & \multicolumn{3}{|l|}{$\mathrm{HBV}$} & \multicolumn{3}{|l|}{$\mathrm{HCV}$} \\
\hline & No. (\%) & OR $(95 \% \mathrm{Cl})$ & $P$-Values & No. (\%) & OR $(95 \% \mathrm{Cl})$ & $P$-Values \\
\hline Exam date & & & 0.34 & & & 0.50 \\
\hline 2010-2012 & $324(2.45)$ & $1.07(0.86,1.33)$ & 0.20 & $49(0.37)$ & $0.98(0.58,1.64)$ & 0.68 \\
\hline 2014-2017 & $502(2.23)$ & $0.93(0.75,1.15)$ & 0.15 & $103(0.46)$ & $1.12(0.69,1.82)$ & 0.48 \\
\hline 2013 & $117(2.21)$ & 1.00 & N/A & $21(0.40)$ & 1.00 & N/A \\
\hline Region & & & $<0.001$ & & & $<0.001$ \\
\hline Africa & $346(5.84)$ & $9.13(6.84,12.19)$ & $<0.001$ & $45(0.76)$ & $5.33(2.88,9.87)$ & $<0.001$ \\
\hline Europe & $114(0.87)$ & $1.04(0.77,1.40)$ & 0.79 & $72(0.55)$ & $3.06(1.72,5.46)$ & $<0.001$ \\
\hline North America & $305(3.35)$ & $2.74(2.08,3.60)$ & $<0.001$ & $38(0.42)$ & $1.53(0.82,2.86)$ & 0.18 \\
\hline South America & 44 (1.94) & $2.22(1.49,3.30)$ & $<0.001$ & $3(0.13)$ & $0.72(0.21,2.51)$ & 0.60 \\
\hline Oceania & $39(5.63)$ & $6.05(4.02,9.10)$ & $<0.001$ & $1(0.14)$ & $0.56(0.07,4.27)$ & 0.57 \\
\hline Asia & $95(0.96)$ & 1.00 & N/A & $14(0.14)$ & 1.00 & N/A \\
\hline Gender & & & $<0.001$ & & & 0.18 \\
\hline Male & $440(1.89)$ & $0.77(0.67,0.89)$ & & $102(0.44)$ & $1.25(0.89,1.74)$ & \\
\hline Female & $503(2.85)$ & 1.00 & N/A & $71(0.40)$ & 1.00 & N/A \\
\hline Age & & & $<0.001$ & & & $<0.001$ \\
\hline$<20$ & $53(0.82)$ & $0.25(0.18,0.35)$ & $<0.001$ & $4(0.06)$ & $0.06(0.02,0.18)$ & $<0.001$ \\
\hline $20-29$ & $202(1.42)$ & $0.38(0.31,0.48)$ & $<0.001$ & $38(0.27)$ & $0.19(0.13,0.30)$ & $<0.001$ \\
\hline $30-39$ & 296(3.02) & $0.76(0.62,0.94)$ & 0.01 & $54(0.55)$ & $0.43(0.29,0.65)$ & $<0.001$ \\
\hline $40-49$ & 209(3.76) & $1.05(0.85,1.30)$ & 0.64 & $29(0.52)$ & $0.48(0.30,0.76)$ & 0.002 \\
\hline$\geq 50$ & 183(3.78) & 1.00 & N/A & 48(0.99) & 1.00 & N/A \\
\hline Educational level & & & $<0.001$ & & & 0.23 \\
\hline Less than high school & $28(7.55)$ & $2.98(1.89,4.69)$ & $<0.001$ & $0(0.00)$ & $<0.00(<0.00,>999)$. & 0.12 \\
\hline High school & $161(1.52)$ & $1.39(1.05,1.84)$ & 0.02 & $28(0.26)$ & $1.10(0.58,2.08)$ & 0.18 \\
\hline Undergraduate & $435(2.31)$ & $0.83(0.67,1.04)$ & 0.11 & $90(0.48)$ & $0.74(0.45,1.24)$ & 0.17 \\
\hline Bachelor's degree & $214(2.82)$ & $1.38(1.07,1.78)$ & 0.01 & $34(0.45)$ & $0.95(0.52,1.73)$ & 0.54 \\
\hline Others & $105(2.94)$ & 1.00 & N/A & $21(0.59)$ & 1.00 & N/A \\
\hline Occupation & & & $<0.001$ & & & $<0.001$ \\
\hline Businessmen & $127(1.29)$ & $0.31(0.25,0.38)$ & $<0.001$ & $14(0.14)$ & $0.16(0.09,0.28)$ & $<0.001$ \\
\hline Designers & $105(2.18)$ & $0.30(0.24,0.38)$ & $<0.001$ & $23(0.48)$ & $0.40(0.25,0.65)$ & $<0.001$ \\
\hline Students & $250(2.07)$ & $0.57(0.48,0.68)$ & $<0.001$ & $33(0.27)$ & $0.36(0.24,0.54)$ & $<0.001$ \\
\hline Unemployed & $21(0.83)$ & $0.16(0.10,0.25)$ & $<0.001$ & $1(0.04)$ & $0.04(0.01,0.31)$ & 0.002 \\
\hline Others & $440(3.79)$ & 1.00 & N/A & $102(0.88)$ & 1.00 & N/A \\
\hline
\end{tabular}

No., OR, N/A and $95 \% \mathrm{Cl}$ represent Number, Odd Rate, No data and 95\% confidence interval, respectively

There are several limitations to this study that should be mentioned. First, this article used the secondary data, so the genotypes of various sexually transmitted diseases pathogens were not clear. Second, HIV cases were too small to perform a multiple linear regression, decision trees, or other statistical methods used for analysis [29]. Third, all foreigners who arrive in Guangzhou will accept a physical examination, but some data are incomplete and we removed these data from our study, which may bias the results.

\section{Conclusion}

In conclusion, the epidemiologic data presented in this paper showed the presence of STIs prevalence in foreigners living in Guangzhou. This study showed a low prevalence of STIs among foreigners. Some prevalence were consistent with the local trends. 
Table 4 Associations of HIV/TPPA with different social demographic characteristics

\begin{tabular}{|c|c|c|c|c|c|c|}
\hline \multirow[b]{2}{*}{ Characteristics } & \multicolumn{3}{|l|}{ HIV } & \multicolumn{3}{|l|}{ TPPA } \\
\hline & No.(\%) & OR(95\%Cl) & $P$-Values & No. (\%) & OR(95\%CI) & $P$-Values \\
\hline Exam date & & & 0.99 & & & 0.33 \\
\hline 2010-2012 & $0(0.00)$ & $0.96(<0.00,>999)$. & 0.92 & $49(0.37)$ & $1.27(0.82,1.96)$ & 0.24 \\
\hline 2014-2017 & $7(0.03)$ & $>$ 999. $(<0.00,>999)$. & 0.78 & $103(0.46)$ & $1.12(0.73,1.71)$ & 0.96 \\
\hline 2013 & $0(0.00)$ & 1.00 & N/A & $21(0.40)$ & 1.00 & N/A \\
\hline Region & & & 0.50 & & & $<0.001$ \\
\hline Africa & $2(0.03)$ & $1.27(0.05,32.17)$ & 0.34 & $81(1.37)$ & $17.18(8.17,36.11)$ & $<0.001$ \\
\hline Europe & $4(0.03)$ & $1.03(0.06,18.35)$ & 0.18 & $76(0.58)$ & $7.34(3.53,15.27)$ & $<0.001$ \\
\hline North America & $0(0.00)$ & $<0.00(<0.00,>999)$. & 0.14 & $46(0.51)$ & $5.00(2.34,10.68)$ & $<0.001$ \\
\hline South America & $0(0.00)$ & $<0.00(<0.00,>999)$. & 0.54 & $31(1.37)$ & $19.30(8.81,42.29)$ & $<0.001$ \\
\hline Oceania & $0(0.00)$ & $0.00(<0.00,>999)$. & 0.71 & $4(0.58)$ & $4.58(1.36,15.42)$ & 0.01 \\
\hline Asia & $1(0.01)$ & 1.00 & N/A & $8(0.08)$ & 1.00 & N/A \\
\hline Gender & & & 0.95 & & & 0.65 \\
\hline male & $4(0.02)$ & $1.14(0.21,6.33)$ & & $127(0.54)$ & $0.97(0.73,1.28)$ & \\
\hline female & $3(0.02)$ & 1.00 & N/A & $119(0.68)$ & 1.00 & N/A \\
\hline Age & & & 0.46 & & & $<0.001$ \\
\hline$<20$ & $0(0)$ & $<0.00(<0.00,>999)$. & 0.98 & $10(0.15)$ & $0.10(0.05,0.20)$ & $<0.001$ \\
\hline $20-29$ & $1(0.01)$ & $0.19(0.01,3.13)$ & 0.46 & $42(0.30)$ & $0.16(0.10,0.24)$ & $<0.001$ \\
\hline $30-39$ & $5(0.05)$ & $1.42(0.16,12.90)$ & 0.39 & $87(0.89)$ & $0.51(0.36,0.72)$ & $<0.001$ \\
\hline $40-49$ & $0(0)$ & $<0.00(<0.00,>999)$. & 0.98 & $45(0.81)$ & $0.54(0.37,0.81)$ & 0.003 \\
\hline$\geq 50$ & $1(0.02)$ & 1.00 & N/A & $62(1.28)$ & 1.00 & N/A \\
\hline Educational level & & & 0.87 & & & 0.12 \\
\hline Less than high school & $0(0.00)$ & $1.41(<0.00,>999)$. & 0.81 & $7(1.89)$ & $0.92(0.38,2.20)$ & 0.30 \\
\hline High school & $1(0.01)$ & $626.90(<0.00,>999)$. & 0.69 & $42(0.40)$ & $0.68(0.41,1.11)$ & 0.78 \\
\hline Undergraduate & $5(0.03)$ & $>999 .(<0.00,>999)$. & 0.29 & $136(0.82)$ & $0.67(0.44,1.02)$ & 0.84 \\
\hline Bachelor's degree & $1(0.01)$ & $409.00(<0.00,>999)$. & 0.58 & $29(0.38)$ & $0.48(0.28,0.83)$ & 0.06 \\
\hline Others & $0(0.00)$ & 1.00 & N/A & $32(0.90)$ & 1.00 & N/A \\
\hline Occupation & & & 0.39 & & & $<0.001$ \\
\hline Businessmen & $1(0.01)$ & $0.98(0.06,15.98)$ & 0.46 & $85(0.86)$ & $3.02(2.03,4.49)$ & $<0.001$ \\
\hline Designers & $2(0.04)$ & $3.05(0.26,35.20)$ & 0.19 & $70(1.45)$ & $3.83(2.49,5.90)$ & $<0.001$ \\
\hline Students & $3(0.02)$ & $3.55(0.36,35.37)$ & 0.23 & $54(0.45)$ & $1.98(1.29,3.06)$ & 0.002 \\
\hline Unemployed & $0(0.00)$ & $0.00(<0.00,>999)$. & 0.47 & $2(0.08)$ & $0.32(0.08,1.34)$ & 0.12 \\
\hline Others & $1(0.01)$ & 1.00 & N/A & $35(0.30)$ & 1.00 & N/A \\
\hline
\end{tabular}

No., OR, N/A, and 95\% Cl represent Number, Odd Rate, No data, and 95\% confidence interval, respectively

During the survey period, there was no significant decline trend in the prevalence of HBV, HCV, HIV, and T. pallidum, so we highlight the need to strengthen the current surveillance program. More observation studies on STIs burden, risk factors, and interventions are needed to provide a solid base for planning and policy change [30, 31]. Furthermore, it is essential to take comprehensive measures including this particular group to control and prevent sexually transmitted infections.

\section{Supplementary information}

Supplementary information accompanies this paper at https://doi.org/10. 1186/s12879-020-04995-8.

Additional file 1: Table 1. The prevalence of HBV/HCV/HIV/TPPA detected in samples of 40,935 participants. (XLS $6437 \mathrm{~kb}$ )

\section{Abbreviations}

HIV: Human immunodeficiency virus; HCV: Hepatitis C virus; HBV: Hepatitis B virus; T. pallidum: Treponema pallidum; HBsAg: Hepatitis B viral surface 
antigen; Anti-TPPA: Treponemal Pallidum Particle Agglutination; OR: Odds ratio; Cl: Confidence interval; STIs: Sexually transmitted infections

\section{Acknowledgments}

We thank LetPub (www.letpub.com) for its linguistic assistance during the preparation of this manuscript.

\section{Authors' contributions}

$\mathrm{BC}$ designed the study and wrote the draft of the manuscript. JMZ and JW provided the raw data. LPH, MQF, JLW and YCD analyzed the data. MQF, SXT, JLW and CSW critically revised the article for the important intellectual content. All of the authors read and approved the final manuscript.

\section{Funding}

This research is supported by funding from the Guangzhou Health Care Collaborative Innovation Major Project (No.201704020219) and co-funded by the Project of the Guangdong Key Laboratory of Tropical Diseases (RDBYJ2018001), administered by Southern Medical University. The funders had no role in the study design, data collection and analysis, decision to publish, or preparation of the paper.

\section{Availability of data and materials}

The data used and/or analyzed during the current study available from the corresponding author on reasonable request.

\section{Ethics approval and consent to participate}

This study was reviewed and approved by the Guangdong International Travel Healthcare Center Institutional Review Board Committee. As only secondary data was used in this study, consent to participate was not required.

\section{Consent for publication}

Not applicable.

\section{Competing interests}

The authors declare that they have no competing interests.

\section{Author details}

'Department of Microbiology, School of Public Health, Southern Medical University, Guangzhou 510515, China. ${ }^{2}$ Clinical laboratory, Guangdong International Travel Health Care Center, Guangzhou 510635, China. ${ }^{3}$ Department of Epidemiology, School of Public Health, Southern Medical University, Guangzhou 510515, Guangdong, China. ${ }^{4}$ Key Laboratory of Tropical Disease Research of Guangdong Province, Southern Medical University, Guangzhou 510515, China.

\section{Received: 30 October 2019 Accepted: 27 March 2020 Published online: 14 May 2020}

\section{References}

1. Karabaev BB, Beisheeva NJ, Satybaldieva AB, Ismailova AD, Pessler F, Akmatov MK. Seroprevalence of hepatitis $B$, hepatitis $C$, human immunodeficiency virus, Treponema pallidum, and co-infections among blood donors in Kyrgyzstan: a retrospective analysis (2013-2015). Infect Dis Poverty. 2017;6(1):45

2. Nayagam S, Thursz M, Sicuri E, Conteh L, Wiktor S, Low-Beer D, Hallett TB. Requirements for global elimination of hepatitis B: a modelling study. Lancet Infect Dis. 2016;16(12):1399-408.

3. Okoroiwu HU, Okafor IM, Asemota EA, Okpokam DC. Seroprevalence of transfusion-transmissible infections (HBV, HCV, syphilis and HIV) among prospective blood donors in a tertiary health care facility in Calabar, Nigeria; an eleven years evaluation. BMC Public Health. 2018;18(1):645.

4. Perz JF, Armstrong GL, Farrington LA, Hutin YJ, Bell BP. The contributions of hepatitis $B$ virus and hepatitis $C$ virus infections to cirrhosis and primary liver cancer worldwide. J Hepatol. 2006;45(4):529-38.

5. Aparna S, Johannes H, Rafael TM, Gérard K, J Rdis JO. Estimations of worldwide prevalence of chronic hepatitis B virus infection: a systematic review of data published between 1965 and 2013. Lancet (London, England). 2015;386(10003):1515-1517.
6. Mohd HK, Groeger J, Flaxman AD, Wiersma ST. Global epidemiology of hepatitis $C$ virus infection: new estimates of age-specific antibody to HCV seroprevalence. Hepatology. 2013;57(4):1333-42.

7. Zou H, Zhang L, Chow EPF, Tang W, Wang Z. Testing for HIV/STIs in China: challenges, opportunities, and innovations. Biomed Res Int. 2017; 2017:1-3.

8. Newman L, Rowley J, Vander Hoorn S, Wijesooriya NS, Unemo M, Low N, Stevens G, Gottlieb S, Kiarie J, Temmerman M. Global estimates of the prevalence and incidence of four curable sexually transmitted infections in 2012 based on systematic review and global reporting. PLoS One. 2015; 10(12):e143304

9. Ruan Y, Luo F, Jia Y, Li X, Li Q, Liang H, Zhang X, Li D, Shi W, Freeman JM, et al. Risk factors for syphilis and prevalence of HIV, hepatitis B and C among men who have sex with men in Beijing, China: implications for HIV prevention. AIDS Behav. 2009;13(4):663-70.

10. Moss GB, Kreiss JK. The interrelationship between human immunodeficiency virus infection and other sexually transmitted diseases. Med Clin North Am. 1990;74(6):1647-60.

11. Xu J, Yu Y, Hu Q, Yan H, Wang Z, Lu L, Zhuang M, Chen X, Fu J, Tang $W$, et al. Treatment-seeking behaviour and barriers to service access for sexually transmitted diseases among men who have sex with men in China: a multicentre cross-sectional survey. Infect Dis Poverty. 2017;6(1):15.

12. Zhang $L$, Chow EPF, Su S, Yiu WL, Zhang $X$, lu Kl, Tung $K$, Zhao $R$, Sun $P$, Sun $X$, et al. A systematic review and meta-analysis of the prevalence, trends, and geographical distribution of HIV among Chinese female sex workers (2000-2011): implications for preventing sexually transmitted HIV. Int J Infect Dis. 2015:39:76-86.

13. Chen XS, Peeling RW, Yin YP, Mabey DC. The epidemic of sexually transmitted infections in China: implications for control and future perspectives. BMC Med. 2011;9:111

14. Cui F, Shen L, Li L, Wang H, Wang F, Bi S, Liu J, Zhang G, Wang F, Zheng H, et al. Prevention of chronic hepatitis B after 3 decades of escalating vaccination policy, China. Emerg Infect Dis. 2017:23(5):765-72.

15. Loua A, Sonoo J, Musango L, Nikiema JB, Lapnet-Moustapha T. Blood safety status in WHO African region countries: lessons learnt from Mauritius. J Blood Transfus. 2017;2017:1-8.

16. Nwobegahay J, Achiangia Njukeng $P$, Kengne M, Roger Ayangma C, Mbozo $O$, Abeng E, Nkeza A, Tamoufe U: Prevalence of Hepatitis B virus infection among blood donors at the Yaounde Military Hospital, Cameroon. Micro Res In. 2016:2(4):6-10.

17. Bala J, Kawo AH, Dauda M, Musa Sarki A, Magaji N, Aliyu I, Sani N. Prevalence of hepatitis $C$ virus infection among blood donors in some selected hospitals in Kano, Nigeria: Res J Microbiol. 2012;3(6):217-22.

18. Liakina $V$, Valantinas J. Anti-HCV prevalence in the general population of Lithuania. Med Sci Mo. 2012;18(3):PH28-PH35

19. Toy M, Onder O, Marschall T, Bozdayi M, Schalm S, Borsboom G, van Rosmalen J, Richardus J, Yurdaydin C. Age- and region-specific hepatitis B prevalence in Turkey estimated using generalized linear mixed models: A systematic review. BMC Infect Dis. 2011;11(1):337.

20. Erhabor O, Ejele OA, Nwauche CA. The risk of transfusion-acquired hepatitis$C$ virus infection among blood donors in Port Harcourt: the question of blood safety in Nigeria. Niger J Clin Pract. 2006:9(1):18-21.

21. Mohammed $Y$, Bekele A. Seroprevalence of transfusion transmitted infection among blood donors at Jijiga blood bank, Eastern Ethiopia: retrospective 4 years study. BMC Res Notes. 2016;9(1):129.

22. Li C, Xiao X, Yin H, He M, Li J, Dai Y, Fu Y, Ge J, Yang Y, Luan Y, et al. Prevalence and prevalence trends of transfusion transmissible infections among blood donors at four Chinese regional blood centers between 2000 and 2010. J Transl Med. 2012:10(1):176.

23. Ji Z, Li C, Lv Y, Cao W, Chen Y, Chen X, Tian M, Li J, An Q, Shao Z: The prevalence and trends of transfusion-transmissible infectious pathogens among first-time, voluntary blood donors in Xi'an, China between 1999 and 2009. Int J Infect Dis. 2012:17(4):e256-62.

24. Yan S, Ying B, Max P, Carolina Oi Lam U. Prevalence and trend of major transfusion-transmissible infections among blood donors in Western China, 2005 through 2010. PLoS One. 2014;9(4):e94528.

25. Yang S, Jiao D, Liu C, Lv M, Li S, Chen Z, Deng Y, Zhao Y, Li J. Seroprevalence of human immunodeficiency virus, hepatitis $B$ and $C$ viruses, and Treponema pallidum infections among blood donors at Shiyan, Central China. BMC Infect Dis. 2016;16(1):531. 
26. Rockstroh J, David Hardy W. Current treatment options for hepatitis $C$ patients co-infected with HIV. Expert Rev Gastroenterol Hepatol. 2016;10(6): 689-95.

27. Martin-Carbonero L, et al. Liver fibrosis in patients with chronic hepatitis $C$ and persistently normal liver enzymes: influence of HIV infection. J Viral Hepatitis. 2009;16(11):790-95.

28. De Ledinghen V, Barreiro P, Foucher J, Labarga P, Castera L, Vispo ME, Bernard PH, Martin-Carbonero L, Neau D, García-Gascó P, et al. Liver fibrosis on account of chronic hepatitis $\mathrm{C}$ is more severe in HIV-positive than HIVnegative patients despite antiretroviral therapy. J Viral Hepatitis. 2008;15(6): 427-433.

29. Verhofstede C, Fransen K, Van Den Heuvel A, Van Laethem K, Ruelle J, Vancutsem E, Stoffels K, Van den Wijngaert S, Delforge M, Vaira D, et al. Decision tree for accurate infection timing in individuals newly diagnosed with HIV-1 infection. BMC Infect Dis. 2017;17(1):738.

30. Zhu B, Liu J, Fu Y, Zhang B, Mao Y. Spatio-temporal epidemiology of viral hepatitis in China (2003-2015): implications for prevention and control policies. Int J Env Res Pub He. 2018;15(4):661.

31. Wendland EM, Horvath JDC, Kops NL, Bessel M, Caierão J, Hohenberger GF, Domingues CM, Maranhão AGK, de Souza FMA, Benzaken AS. Sexual behavior across the transition to adulthood and sexually transmitted infections. Medicine. 2018:97(33):e11758.

\section{Publisher's Note}

Springer Nature remains neutral with regard to jurisdictional claims in published maps and institutional affiliations.

Ready to submit your research? Choose BMC and benefit from:

- fast, convenient online submission

- thorough peer review by experienced researchers in your field

- rapid publication on acceptance

- support for research data, including large and complex data types

- gold Open Access which fosters wider collaboration and increased citations

- maximum visibility for your research: over $100 \mathrm{M}$ website views per year

At BMC, research is always in progress.

Learn more biomedcentral.com/submissions 